$\xi=-1$

\title{
Bad Friday, Monday Effect and Political Issue: Application of ARCH-GARCH Model to Analyze Seasonal Pattern of Stock Return
}

\author{
Maria Rio Rita ${ }^{1}$, Sugeng Wahyudi ${ }^{2}$, Harjum Muharam ${ }^{3}$ \\ ${ }^{1}$ Economics and Business Faculty of Diponegoro University. Indonesia \\ ${ }^{1}$ Economics and Business Faculty of Satya Wacana Christian University. Indonesia \\ ${ }^{2}$ Economics and Business Faculty of Diponegoro University. Indonesia \\ ${ }^{3}$ Economics and Business Faculty of Diponegoro University. Indonesia \\ *Corresponding author E-mail: maria.riorita@staff.uksw.edu
}

\begin{abstract}
At the end of 2016, Indonesia was shaken by a demonstration of the election of the Governor of Jakarta Capital Special Region and political issues related to religious defamation. Does this condition have an impact on stock prices and returns? The aim of this study is to test the week day pattern in IDX using LQ-45 stocks during selected observation period of August 2016-January 2017. Then a GARCH model is used to investigate the presence of week day pattern in the stock market. Therefore, the GARCH model is able to describe observed statistical characteristics of many time series of financial assets return. The test results show that there is a difference in average stock return during the trading day. The lowest and the highest return are observed on Monday and Wednesday, respectively. Meanwhile, the average negative return on Friday is not proven to significantly drive the occurrence of Monday effect. Return on Monday is influenced by the frequency of trading, not by trading volume. Is there anything to do with the psychological aspect of investors solely in assessing risk acceptance to stocks? Research agenda related to this is very relevant to do in the future.
\end{abstract}

Keywords: Monday Effect; Bad Friday; Political Issue; Stock Return; ARCH-GARCH

\section{Introduction}

For about the last six months of 2016, there were many demonstrations on Fridays due to the Governor elections in Jakarta and the religious desecration incident that surrounded the political incident. In September 2016, PDI Perjuangan proposed Ahok as the Governor candidate. This news directly made Indonesian society, especially Jakarta, start to be exposed by various issues in social media. The second incident was the case/accusation of religious defamation that was done by Basuki Tjahaja Purnama (Ahok), which ended in large demonstrations from the middle until the end of 2016. These demonstrations were generally done on Fridays, such as on 16 September, 14 October, 21 October, 4 November, 25 November, and 2 December 2016. Did this condition have an effect on the stock prices and returns?

The condition of the capital market cannot be separated from the political condition of a country. If the political condition is conducive, then the stock prices will increase, whereas if the political condition is unstable or chaotic, then the stock prices and returns will decrease (1-3). Meanwhile, it is suspected that the political condition can influence the high or low stock returns, especially on Fridays. Besides the political incidents for the last 6 months of 2016, several empirical facts show that there were also bad anomalies on Fridays (bad Fridays), where issuers received negative returns for their stocks on Fridays (4-6). What happens in a regular political condition then becomes a bad Friday, moreover if it is added to political and social uproar, as well as the intensive news in social media that makes the news become unpredictable and spread quickly. There are indications and previous research that state that on bad Fridays, this will carry over to Mondays, which is known as the 'Monday effect' (4-5, 7-8). This means that negative returns on a Friday will continue on the following Monday. Is that research also still consistent from the last 6 months of 2016 with an abnormal political condition?

Previous research also sought out the causes of the effects on Mondays. However, there has not been research that especially studies the influence of trading volume and stock frequency towards the effects on Mondays. As is known, there is a relationship between stock liquidity and an increase in stock prices through investor expectations to receive profit from their stock sales. Policyholders in the stock market take advantage of the trading volume, prices, and frequencies to measure stock liquidity. This means that there could be stock returns related with the trading volume and frequency (9-10). Meanwhile, other research reveals that the stock volume and/or frequency is not related with stock returns (11).

Calculating stock returns is usually done on a long-term basis, even for dozens of years. In such a condition, stock returns can be influenced by several factors and incidents that are difficult to be controlled. Research results on stock returns can have potential confounding effects that may disrupt observable stock return estimations (12-14). Related with this, research needs to be conducted on stock returns that are analyzed for a shorter period of less than one year.

Besides these aspects above, there are bad Friday and Monday effects that still raise questions, keeping in mind that there has 
been various research on this topic. Several pro findings related with bad Fridays were found in some research $(4,5)$. Meanwhile, contra research results were also discovered about bad Fridays (Cross, 1973). There are also those who agree with the Monday effects Bessembinder and Hertzel (15), Cross (16), French (17), Fishe, Gosnell (18), Ajayi, Mehdian (19), Berument and Kiymaz (20). They stated that average returns on Fridays were higher than average returns on Mondays, or returns on Mondays were lower than returns on Fridays. Najand and Yung (21) documented that the Monday effect phenomenon not only pertains to stocks, but it is also experienced in other financial assets like treasury bills (22, $23)$; treasury bonds $(24,25)$; and foreign exchange markets $(26$, 27). Meanwhile, other research results showed that Monday effects could not be proven during an economic crisis (28) but Muhammad and Rahman (29) found otherwise. This implies that there are inconsistencies from previous studies on Monday effects. As a result, further research is still needed to find more conclusive deductions regarding this.

Previous research that was done on international financial markets mostly examined the return average seasonal patterns as well as financial asset price volatility using a generalized autoregressive conditional heteroscedasticity (GARCH) model variation $(30,31)$. The GARCH specifications were evaluated as being more appropriate compared with a standard statistical model, because GARCH is consistent with return distributions which tend to be leptokurtic, and the model allows for the presence of long-term historic data in return distribution variation. Therefore, Najand and Yung (21) and Bauwens and Laurent (32) considered the GARCH model as being able to represent statistical data characteristics that could be observed from financial asset return time series data Berument and Kiymaz (20) did not only study the stock return seasonal patterns, but they also tested whether there were any stock return volatility variations/deviations on a trading day. Information regarding stock price changes during a transaction day in the stock market is related with the time or when transaction activities are conducted for investors. These return volatility predictions are advantageous for investors to readjust their portfolios by reducing assets that have high volatility as well as for hedging strategies.

The method of calculating stock returns generally uses a regression analysis by applying real stock return data. By having the ARCH-GARCH method, it facilitates projections with a data condition that is already stationary. Based on researcher observations, there is no known research that examines the predictability of Monday effect stock returns for stocks that are classified as LQ-45 in one day (intra-day pattern), based on company characteristics like trading volume and trading frequency using the GARCH model, especially when the political condition is unstable. Therefore, related with this goal, the GARCH model will be applied to test the presence of the return pattern phenomenon during the day of the week pattern in the stock exchange. The purpose of this research is to depict the stock seasonal return pattern. This can be done by following three examination stages: to predict whether there is a day of the week pattern in the stock exchange, to see whether negative Friday returns (bad Fridays) have an effect on the Monday negative return averages (bad Mondays), as well as to predict the causes of return changes on Mondays based on trading frequency and volume.

\section{Literature Review}

Market efficiency refers to what extent stock prices and other security prices reflect all of the available and relevant information. Investors are unable to win the market because all of the available information is already reflected in all of the stock prices (33) Hypotheses regarding an efficient market can be divided into three groups based on the classifications of the efficient market hypotheses tested (34). This research focuses on assessing whether there is market efficiency in a weak form, meaning by assessing returns based on monthly, weekly, and daily patterns. The stocks examined are classified in a liquid 45 group (LQ-45) to avoid the slight trading transactions during the observation period. It gives meaning to market anomalies as a form of efficient market violation. The kinds of market anomalies that are often discussed include market to book ratio, PER, and company measurement. In line with the financial market research dynamic, the market anomalies are more various with discovering daily effects, weekend effects, and January effects. As for the stock exchange daily effects on stock return fluctuations, it makes the returns not diversified during the transactions. An indication that can be explained is there are differences in investor preferences in conducting transactions at that time, which result in return changes.

\subsection{Changes in Average Daily Returns in a Week (Weekday Effect)}

Based on the weekday effect phenomenon, in every day in a week, there are different daily return averages. Previous research $(17,23$, 35,36 ) revealed a weekday effect, meaning a Monday effect and a Friday effect. A Monday effect is a condition where negative stock returns are significant on that day, so that the Monday effect occurs when the Monday average returns are smaller than the average returns on another day besides Monday. As for the trading day effects discovered from findings by Cross (16) in the United States financial market, there are differences in stock returns on Fridays and Mondays. Furthermore, these trading day effects were elaborated by French (17), who reported that the highest and the lowest returns are on Fridays and Mondays. According to McGowan Jr and Ibrihim (37), these trading day effects occur in developed financial markets or developing financial markets, where the highest and the lowest returns do not always happen on Fridays and Mondays.

Previous studies already explored the causes of Monday effects, such as investor psychology. This psychological aspect is due to a pessimistic feeling on Mondays and an optimistic feeling on Fridays. There are not only pessimistic and optimistic feelings, but there is also a feeling of going along with the trend in stock market trading activities. Usually on Fridays, investors are enthusiastic or looking forward to the weekend. Meanwhile, on Mondays, they are still influenced by the weekend condition, so that they are not as motivated to engage in transactions. As a result of spreading to stock prices, it influences stock returns. The effects of trading transactions can change every day due to the influence of investor behavior $(16,38,39)$. With an argumentation like this, the following hypothesis can be formulated:

Hypothesis 1: The average daily returns are different in a week (weekday effect) in the stock exchange.

\subsection{The Friday Stock Returns Influence the Monday Stock Returns (Friday-Monday Day of the Week Effects)}

Previous research has confirmed that stock returns on Mondays have a negative value (profit loss) (Cross, 1973; French, 1980(40)). Cross (1973) stated that in 5 years of research, the stock return averages on Mondays were always negative. These results imply that the market is inefficient. Meanwhile, Wang, $\mathrm{Li}$ (41) stated that in one month, the Monday returns in the fourth and fifth weeks were negative. This was due to information announced in the previous trading session. This finding reveals that Friday returns influenced Monday returns. In other words, if there are negative returns on Fridays, it can still have a negative effect on Monday returns.

Jaffe, Westerfield (42) discovered that abnormally low returns on a Monday appear to follow a stock market decrease. Actually, the Monday effect is almost non-existent when the previous market increases. This means that the low returns on Mondays do not exist independently; there is a connection with Friday returns. 
Monday returns have a positive correlation with the previous Friday returns. Their finding elaborated that even after one calculation for the next Friday-Monday correlation. Hirshleifer and Shumway (43) and Michayluk and Neuhauser (44) supported this where negative returns that occur on a Monday are a continuation of the effect of negative returns on that Friday. The stock sales transactions on Mondays will be more intense when the stocks experience bad Fridays on the previous week. The high level of offers will impact the condition in the stock market, which can cause stock prices to weaken, so that it will continue with negative returns on the next Monday. With this kind of an argumentation, the following hypothesis can be formulated:

Hypothesis 2: Stock price returns on a Friday influence stock price returns on the following Monday

\subsection{Influence of Trading Volume and Frequency To- wards Friday and Monday Stock Price Returns}

There is no general common agreement regarding what variables can become the best predictors to determine stock returns, but several company characteristics can become items for consideration when choosing stocks for the first time (45). The relationship between company characteristics (like company measurement, earnings, and market to book value) with abnormal returns has been frequently documented. As for this relationship pattern, it shows that the market is inefficient, because there are still opportunities for investors to obtain abnormal returns. The market efficiency theory explains that no one is able to obtain abnormal returns based on information about company characteristics. Pas research carried out by Banz (1981); Basu (1983) and Malkiel (46) about the size effect reveals there is a pattern where small company stocks actually have higher returns compared with big company stocks. Meanwhile, Fama and French (1992); Lakonishok, Shleifer (47); and Drew, Naughton (48) researched the relationship between market to book value and stock returns. Another finding stated that stocks with a small $\mathrm{P} / \mathrm{E}$ ratio will obtain higher return averages than stocks with a high $\mathrm{P} / \mathrm{E}$ ratio (49-51).

Other studies on company characteristics and stock returns were also researched, such as the kinds of industries (52); concentrated industries (53); and exchange value exposure towards industry returns (54). In addition, stock liquid proxies like trading volume can also be connected with stock returns $(9,11,55)$. Another proxy is seen from the frequency of stock trading, where the high or low frequency of trading in stocks will influence the stock returns. Yadav et al. (1999) mentioned that there is a positive relationship between the trading frequency and stock returns. Elvira (56), who studied Syariah stocks, stated that the trading frequency has a significant and positive relationship towards the stock returns, where big stock trading frequency will increase the stock returns, and the other way around. The high volume of Syariah stock trading indicates that the stocks are sought after by investors, so that it will increase stock prices, which will then increase Syariah stock returns. Liquidity is one of the factors that are strongly considered by investors in making investment decisions $(57,58)$. Stocks with high liquidity will increase the probability to obtain stock returns, which in the end will increase stock prices. So, stocks are considered liquid if the stocks do not have any difficulty in buying or reselling. The stock exchange authority has already used trading volume, prices, and frequency as measurements of stock liquidity. This means that when the volume, value, and frequency are higher, the stock liquidity will also be higher. The proposed hypotheses are as follows:

Hypothesis 3a: The stock return averages on a Monday are influenced by the trading volume and frequency on a Monday.

Hypothesis 3b: The stock return averages on a Monday are influenced by the difference between the trading volume and frequency on a Friday and Monday.

\section{Methodology/Materials}

\subsection{Data Types and Sources}

This research used secondary data that was obtained from the website: www.idx.co.id, which included data about daily closing stock prices, trading volume, and trading frequency of 45 stocks that were included in the LQ-45 list from August 2016 to January 2017. This LQ-45 stock category was chosen to reduce the bias that may occur as a result of having inactive or less active stocks traded during the observation period.

\subsection{Variable Measurement}

There were three variables in this research: daily stock returns, trading volume, and trading frequency of LQ-45 stocks during the research period. The variable measurements are described below:

a. Daily stock returns are the ratio between the difference of one day's closing stock prices with the previous day's closing stock prices. The formula is:

Return $_{i t}=\frac{P_{i t}-P_{i t-1}}{P_{i t-1}}$

Where:

Rit : Stock return i on the $t$ day

Pit : Stock closing prices $i$ on the $t$ day

Pit-1 : Stock closing prices i on the t-1 day

b. What is meant by the trading volume here is the number of stock shares of an issuer that are traded in the stock exchange, especially on a Monday.

c. The trading frequency shows the trading intensity done for a certain period, where the frequency reflects the flow of information that is received by the investors.

d. The trading difference/ delta volume is obtained by reducing the trading volume on a Monday (Vis) with Friday (Vij).

$$
\Delta V_{-}\left(\mathrm{it}=\mathrm{V} \_ \text {is- }-\mathrm{V} \_\mathrm{ij}\right. \text { ) }
$$

e. The trading difference/ delta frequency is obtained by reducing the trading frequency on a Monday (Fis) with Friday (Fij)

$$
\Delta F \_ \text {(it }=F \_ \text {is-F_ij ) }
$$

\subsection{Analysis Method}

Testing hypothesis 1 . Testing the differences in the stock daily return averages was done by using a Kruskal-Wallis test on an independent k-sample to find out whether the value of a variable displayed a difference with two or more groups (59). If the p-value $>0.05$, then the Ho could not be rejected. In contrast, if the pvalue $<0.05$, then there was enough evidence to reject the Ho.

Testing hypothesis 2 . Testing the influence of negative returns on a Friday on the previous week towards the positive returns on the next Monday (Monday effect) was done with an ARCH-GARCH estimation method, which was processed with EVIEWS 8 software. The time series data was susceptible towards the problem of heteroskedasticity, where there were error disturbances that did not have the same variance (inconsistent) during the observation period. This condition resulted in the modeling and predicting by using the ARIMA Box Jenkins to be no longer valid. An estimation method was needed to model the volatility from the data by using the ARCH-GARCH model. The ARCH-GARCH model then became an important analysis instrument in the time series data, especially in applying the financial data that was beneficial for the analysis and volatility predictions.

The dynamic process modeling from the intra-day volatility series of ARCH (AutoregressiveeConditional Heteroskedasticity) and GARCH (GeneralizeddAutoregressive Conditional Heteroskedasticity) was formulated by Engle (60) and Bollerslev (61). This 
technique was modeled simultaneously between the mean and error variant, which was devised by Engle (60), when modeling inflation in England with the ARCH model. It was continued by Bollerslev (61), who published a general form of $\mathrm{ARCH}$, which was called GeneralizeddAutoregressive Conditional Heteroskedasticity (GARCH). Volatility occurred with the effect of news entering a market towards the volatility that occurred in another market that could be analyzed by using a vector autoregression method (62). Both of these models tolerated having return variance during the observation period. The appearance of a variance at a particular time depended on another variable or disturbance from the previous period. Baillie and Bollerslev (63) stated that the assumption of normality in ARCH produced several degrees of excess kurtosis. These models are often used to model changes in stock returns by several researchers (64-66). The data needed for this test involved LQ-45 stock return averages on a Friday $\left(\mathrm{R}_{\mathrm{iJ}}\right)$ and LQ-45 stock return averages on a Monday $\left(\mathrm{R}_{\mathrm{is}}\right)$. The model used in this research referred to McGowan Jr and Ibrihim (37), which was explained through the following equation:

$$
R_{t}=a_{0}+\beta_{1} R_{t-1}+\varepsilon_{t}
$$

Where

$R_{t}$ : stochastic stock returns

$\beta_{1}$ : regression parameter

$R_{t-1}$ : series from the clarified variable lag

$\varepsilon_{t}:$ error terms

The returns obtained from this process were auto-regressive. The error terms were determined by the vector lag, $\left(\varepsilon_{t}=f\left(\varepsilon_{t-1}, \varepsilon_{t-2}, \varepsilon_{t-3}, \ldots\right)\right.$, normal distribution with zero averages, and variants with the same $\mathrm{h}_{\mathrm{t}}$. The $\varepsilon_{t}$ variant was the same with the quadrat value from the error terms lag and variant value lag.

$h_{t}=\mu+\alpha_{1} \varepsilon_{t-1}^{2}+\alpha_{2} h_{t-1}$

$\varepsilon_{t-1}^{2}$ was produced from the lag error volatility, while $h_{t-1}$ was determined by the error prediction from the previous period $\left(\mathrm{h}_{\mathrm{t}-1}\right.$ $\mathrm{h}_{\mathrm{t}-2}$ ). Equation 4 is an equation from the period return average condition, which was then referred to as an auto regressive process. Equation 5 is a variant equation that was produced from the quadrat lag value, error terms lag $\left(\mathrm{h}_{\mathrm{t}-1}-\mathrm{h}_{\mathrm{t}-2}\right)$. The model tested was a combination of equations 4 and 5, which was:

$$
R_{t}=\beta_{1} R_{t}+a_{1} \varepsilon_{t-1}^{2}+a_{2} h_{t-1}
$$

Based on the ARCH-GARCH estimation model that was done to test hypothesis 2 , whenever the p-value $>0.05$, then the Ho cannot be rejected. However, if the p-value $<0.05$, then Ho is rejected. This means that there was an influence between the Friday returns in the previous week with the Monday return averages.

Testing hypothesis 3 . The third test was done to find out the causes of the Friday-Monday returns. Based on the theories explained above, there were two independent variables tested: the trading volume variable and the trading frequency variable. A simultaneous linear regression was used to test it. For the data two kinds of data were used. The first kind was return average data, volume and frequency on Mondays, because the returns used referred to the stock closing prices. Second, because there were two kinds of data on Fridays and Mondays, a difference (delta) value of trading volume and frequency averages was used for Fridays and Mondays.

\subsection{Results and Findings}

\subsection{Description of Stock Daily Returns}

There were 45 stocks analyzed from August 2016 until January 2017. For the duration of this research, 5,712 observations were obtained for the data. The LQ-45 stock return average movements and the trading volume fluctuations are depicted in Figure 1 and Figure 2 below.

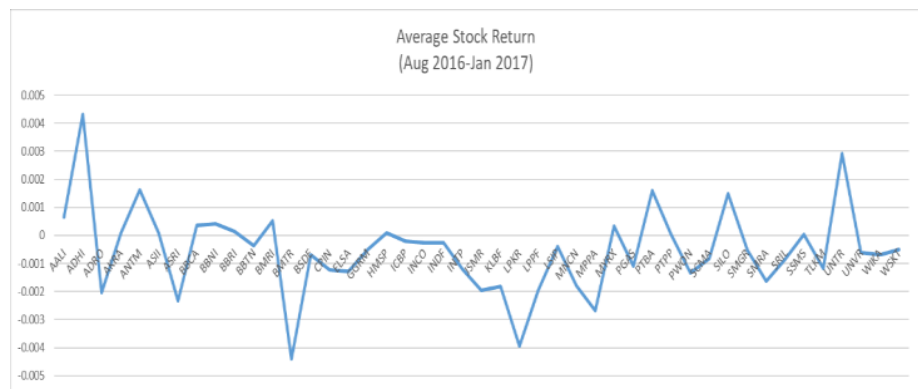

Fig 1:. LQ-45 Stock return averages

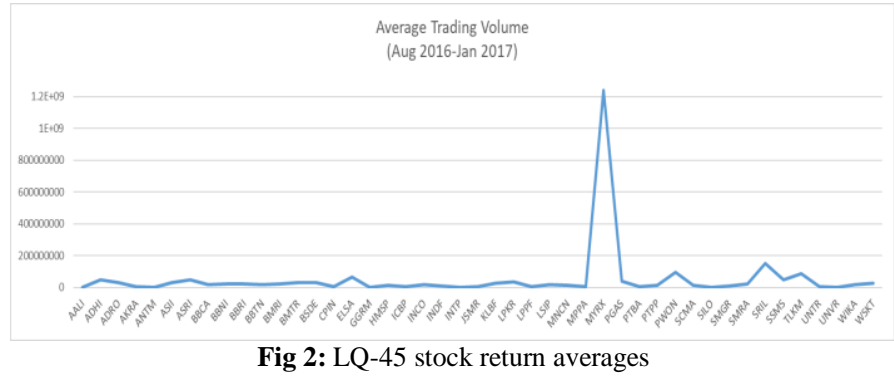

Related with testing the trading daily effects on the stock returns, the following information is provided about the return averages during the stock exchange days to obtain a depiction of the trading condition in the market. From Table 1, it is known that the return averages fluctuated for five days in the stock exchange. On Mondays, return averages were obtained of -0.001 , which were then increased on Tuesdays. The return averages on Tuesdays were offset by the returns on Wednesdays with a reduction of approximately the same as seen in the return level of -0.00003 . The returns were corrected with an increase on Thursday. This may be due to the fact that the investors started to apply their investment strategies to obtain positive returns. However, when approaching the weekend for the stock market, the lowest return averages were recorded at -0.004 . The biggest deviations in standard value were found on Thursdays $(0.025)$, in which the trading risks on that day were higher compared with other days. The lowest return level deviations were found on Mondays at 0.02133 , which infers that transaction risks on Mondays were the lowest if compared with other days. The maximum and minimum values reveal that the lowest returns during the observation period occurred on Tuesdays, at -0.20946 , while the highest returns were on Thursdays, at 0.168 (Table 1).

Table 1: LQ-45 Stock Return Averages on Trading Days

\begin{tabular}{|l|r|c|c|c|r|}
\hline \multicolumn{1}{|c|}{ Day } & \multicolumn{1}{c|}{ Mean } & STD & Min & Max & Observations \\
\hline Monday & -0.001 & $\mathbf{0 . 0 2 1}$ & -0.071 & 0.095 & 990 \\
\hline Tuesday & 0.00002 & 0.023 & $\mathbf{- 0 . 2 0 9}$ & 0.149 & 1,215 \\
\hline Wednesday & -0.00003 & 0.022 & -0.095 & 0.112 & 1,125 \\
\hline Thursday & 0.002 & $\mathbf{0 . 0 2 5}$ & -0.081 & $\mathbf{0 . 1 6 8}$ & 1,170 \\
\hline Friday & -0.004 & 0.023 & -0.159 & 0.116 & 1,170 \\
\hline
\end{tabular}

Source: www.idx.co.id (Processed, 2017).

Besides that, the empirical data implies that there is an interesting phenomenon, where the return averages on two consecutive days tend to reveal negative values, meaning on the Friday of the previous week and Monday (Figure 3). Is this an incident alone or is there a connection between negative returns on a Friday (bad 
Friday) and a Monday (Monday effect)? From the figure, it is clearly seen that the lowest returns were on a Friday, while the highest returns were on a Thursday.

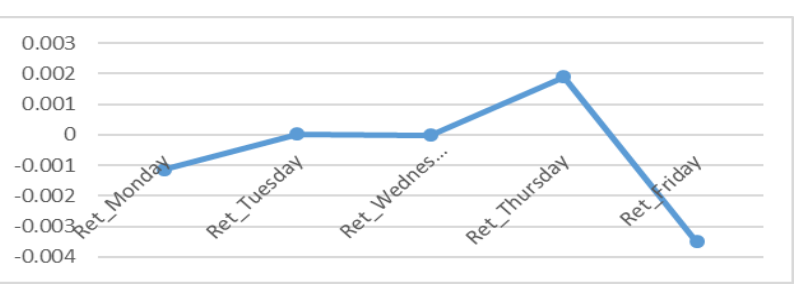

Fig 3: LQ-45 stock daily return averages

If seen from Figure 3, the Friday returns for the last 6 months went down drastically if compared with other days. There were several causes for this. First, there was an election incident in the Jakarta municipal area. In September, PDI Perjuangan appointed Ahok as the Governor candidate. This news immediately made Indonesian society, especially Jakarta, start to be exposed through various issues in social media. The second issue was the religious defamation case/accusation that was done by Ahok, which ended in big demonstrations that occurred from the middle until the end of 2016. These demonstrations were generally done on Fridays, such as the demos on 16 September, 14 October, 21 October, 4 November, 25 November, and 2 December 2016. This unstable political and security condition disrupted the stock market. These incidents had negative reactions from the stock market, so that investors did not want to buy stocks. Even many investors sold their stocks, so that it caused stock prices to go down drastically from a normal day.

The second argumentation was selling stocks after getting profit on a Thursday. When investors saw the stock prices as being high on a Thursday (overvalued), there was a strong tendency to sell their stocks in the stock market on a Friday (profit taking). This selling action was stronger because of the short time at the stock market on a Friday, which was only 4.5 hours, compared with another day. Many investors who sold their stocks caused a reduction in stock prices, which in the end triggered sharp reductions in returns that even became negative. Another factor was there was concern about the schedule or important news in the United States about oil inventory and decisions made by the Federal Open Market Committee (FOMC), which usually surfaced from individual investors, so that it increasingly emphasized a selling position. An FOMC announcement that is made by the federal government can determine changes in US monetary policies, such as interest rates, bond buying programs, monetary stimulus, and others. This will certainly have a great influence on the world capital market condition. The majority of this news was launched on a Friday evening (Asia time). Another argument was that on Fridays there were usually liquidity fulfillment demands from investors, so that on Fridays many stocks were sold in the market. As a result, there was much pressure to sell, so that the stock prices would go down causing negative returns.

\subsection{Testing Weekly Effects (Hypothesis 1)}

Before testing the hypothesis, a data normality test was conducted. This testing was done using a Kolmogorov-Smirnov test with a Liliefors correction, of which the results can be seen in Table 2.

Table 2: Testing Kolmogorov-Smirnov

\begin{tabular}{|l|c|}
\hline \multicolumn{1}{|c|}{ Day } & Kolmogorov-Smirnov ${ }^{\text {a }}$ (Sign.) \\
\hline Monday & $1.2914 \mathrm{E}-12$ \\
\hline Tuesday & $4.8499 \mathrm{E}-16$ \\
\hline Wednesday & $5.4253 \mathrm{E}-26$ \\
\hline Thursday & $8.3464 \mathrm{E}-16$ \\
\hline Friday & $3.2631 \mathrm{E}-16$ \\
\hline \multicolumn{2}{|c|}{ Source: Processed data (2017) } \\
\hline
\end{tabular}

Based on the testing results above, it was discovered that the sample distribution was not normal for all of the stock market days (sig. < 0.05), so that hypothesis 1 was tested with a nonparametric statistic method, which was a Kruskal-Wallis test. This hypothesis was tested by comparing the averages from more than two populations that were mutually independent. The following is the details of the testing results:

Table 3: Kruskal-Wallis Testing Results

\begin{tabular}{|l|l|l|l|}
\hline Return & MeankRank & Statistic Test & \\
\hline Monday & 2783.77 & Chi-Square & 37.265 \\
\hline Tuesday & 2913.57 & Sign. & 0.000065 \\
\hline Wednesday & 2816 & & \\
\hline Thursday & 2979.24 & & \\
\hline Friday & 2673.21 & & \\
\hline
\end{tabular}

Source: Processed data (2017)

Table 3 shows that there is a significance value of $0.000065<$ 0.05 , which means that Ho is rejected. This confirms that there were significant stock return differences for five stock days. This implies that trading days had an influence towards stock returns. This finding is in line with the efficient market anomaly theory, which is that there is a weekday effect/pattern that shows differences in stock returns for a week.

Based on the description of the stock daily return averages (Table 1 ), the Monday effect could be seen from the Monday return averages, which were the lowest compared with the return averages on another day, and the values even became negative. The Monday effect was due to the fact that on Mondays (the beginning of the stock exchange week), most investors tended to take advantage of the moment to study and consider various relevant information to determine transaction strategies (67), so that this made investors tend to delay engaging in stock purchasing transactions. Another indication for the cause in the reduction of stock prices was the induction of many selling actions due to bad information on the previous Friday or the previous trading session. Table 1 conveys that there were anomalies, in that the Friday return averages had the biggest negative value compared with the Monday returns of the next week.

This Monday effect phenomenon could also be explained from the psychological side of investors who generally did not like Mondays as the beginning of the workweek, so that they felt pessimistic when engaging in transactions in the stock market $(36,68-70)$. This indication could be supported from the data in Table 4, in which the lowest trading volume averages were on Mondays. The values were even far below the stock trading volume averages for five stock market days. This reveals that institutional investors did fewer trading activities on this day, while non-institutional/ individual investors did more selling activities during their trading activities. The increase in that supply caused stock prices to experience more pressure.

Table 4: Stock Trading Volume Averages on a Stock Day

\begin{tabular}{|c|c|}
\hline Stock Day & Stock Trading Volume Averages \\
\hline Monday & $48,673,304.38$ \\
\hline Tuesday & $49,858,568.47$ \\
\hline Wednesday & $56,226,436.66$ \\
\hline Thursday & $54,193,133.73$ \\
\hline Friday & $53,289,237.57$ \\
\hline Average & $52,448,136.16$ \\
\hline
\end{tabular}

Source: Processed data (2017)

\subsection{Testing the Relationship of Friday Returns To- wards the Monday Effect (Hypothesis 2)}

From the descriptive statistics calculations, it shows that Monday returns $(-0.001)$ were higher than Friday returns (-0.003) or Friday negative returns (loss) were bigger than Mondays. The low returns on Fridays were due to political incidents, profit taking, and fulfilling investor obligations. 


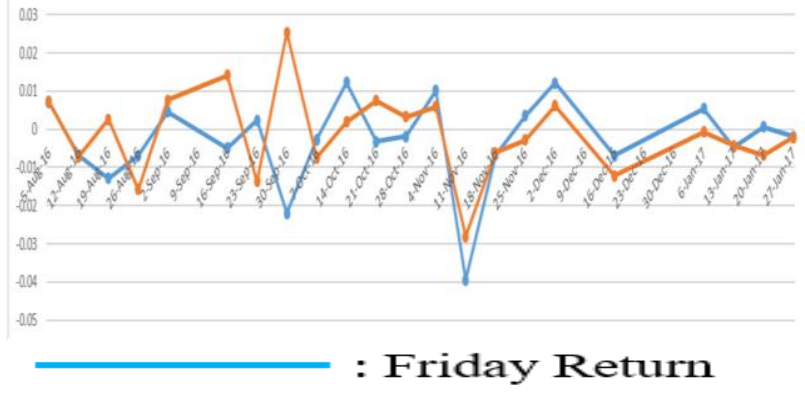

\section{: Monday Return}

Fig 4: LQ-45 Issuer Friday and Monday Return Averages based on Time Series Data

Source: Processed data (2017)

If seen from the time series data for 22 weeks, the LQ-45 stock returns on Fridays and Mondays showed movements in tandem. It was only certain dates that were contrasting like on 19 August, 16, 23, and 30 September (Figure 4). Graphically, it can be seen that there was a relationship between Friday returns and Monday returns. About $60 \%$ of the Friday returns were losses, and about $55 \%$ of the Monday returns were negative or losses.

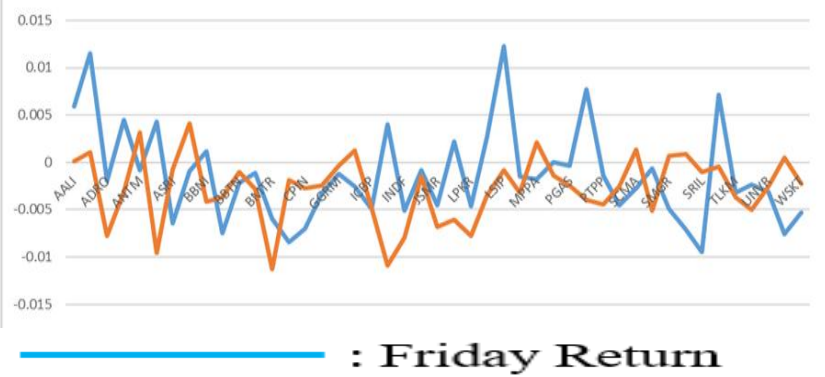

\section{: Monday Return}

Fig 5: LQ-45 Issuer Friday and Monday Return Averages based on Cross Section Data

Source: Processed data (2017)

Figure 5 shows return movements on Fridays and Mondays based on cross section data. Several issuers had positive movements on Mondays compared with Fridays. However, in general, the stock return movements on Mondays were still related with the stock returns on Fridays. There were 35 issuers $(78 \%)$ who recorded losses on Fridays, and about 33 issuers (73\%) recorded losses on Mondays. This means that stock movements on Mondays were not aggressive, and there were still many issuers who experienced stock trading losses on Mondays. What happened with the stock returns on Mondays?

The reduction of stock prices on Fridays indicates that the stock prices were undervalued. This then triggered investors to buy stocks on Mondays with smaller trading volume while waiting for the proper situation to buy more stocks again. Besides that, Mondays are the beginning of the workweek after the holiday, which made investors less motivated or tuned in with doing transactions. This condition is frequently called the Monday effect. The Monday effect anomaly can be explained by previous theories or research results, in that this condition is related with trading activities on Fridays of the previous week. Did this condition occur for LQ-45 stock issuers during trading from August 2016 until January 2017? To respond to this question, hypothesis 2 was tested by using the ARCH-GARCH estimation model through three stages, which examined whether the LQ-45 stock return averages on Mondays (Ris) underwent an $\mathrm{ARCH}$ process or a $\mathrm{GARCH}$ process as well as whether the LQ-45 stock return averages on Mondays (Ris) were influenced by the LQ-45 stock return averages on Fridays of the previous week (RiJ)

\subsection{1 \\ Test \\ Friday and Monday Return Data Stationarity}

Based on Figure 6, the Friday return data can be considered as being stationary, because the movements and fluctuations were average. The stationary data in the graph above was shown with testing the unit roots by using an Augmented Dicky-Fuller (ADF) Test. The ADF test results reveal that the Friday return data is already stationary (sig. $<5 \%$ ), so that there is no need to do differencing.

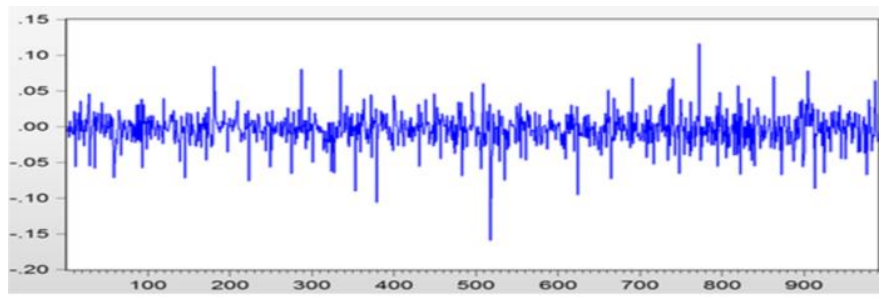

Fig 6: Friday Return Stationarity Pattern

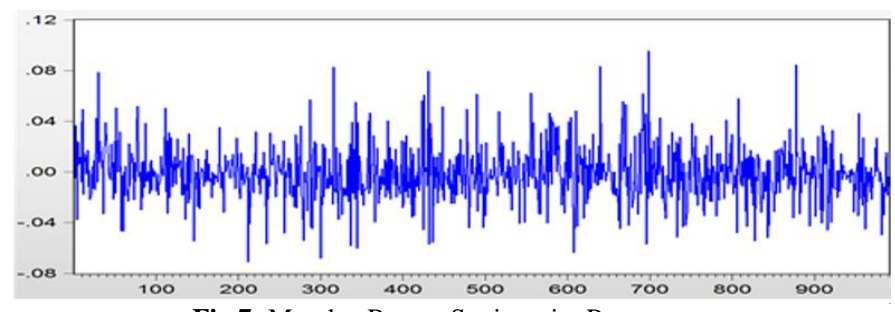

Fig 7: Monday Return Stationarity Pattern

Based on Figure 7, the Monday return data can be considered as stationary, because the movements and fluctuations around it were average. The stationary data in the graph above was also proven with testing the ADF unit roots. The ADF test results in Table 5 show that the Monday return data was already stationary (sig. < $5 \%$ ), so that differencing was not needed.

The next stage estimated the mean equation with the Monday returns as a dependent variable and $\mathrm{C}$ (constant) as an independent variable. Table 5 shows that the constant did not have a significant influence towards the Monday returns (sig. 0.0927), so that for the next test, it would have another independent variable included, which was Friday returns in the estimation model.

Table 5: Monday Return and Mean Equation Estimation

\begin{tabular}{|l|l|l|l|}
\hline Variable & Coefficient & Std. Error & Prob. \\
\hline C & -0.001 & 0.0007 & 0.093 \\
\hline
\end{tabular}

Source: Processed data (2017)

Next, a residual test was carried out to see whether there were ARCH-GARCH elements in the residual from the mean equation above. Table 6 below shows that the ACF and PACF values were not the same as zero in all inactions or significantly statistic at alfa $5 \%$, so that it could be concluded that there were ARCH elements in the mean equation. The residual test above implies that the Monday return model with an independent variable constant had ARCH elements. Next, a re-estimation was done of the mean equation using the ARCH estimation method.

Table 6. Mean Equation Residual Testing

\begin{tabular}{|c|c|c|c|c|c|c|}
\hline Autocorrelation & Partial Correlation & & $A O$ & PAC & a-stat & Prob \\
\hline 政 & 唯 & 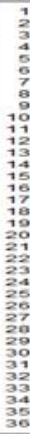 & 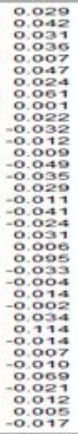 & 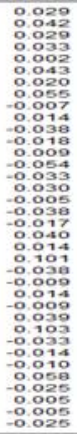 & 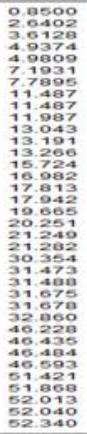 & 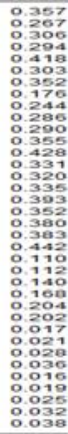 \\
\hline
\end{tabular}


The equation that was delivered from the estimation results above can be stated as follows (Table 7):

Monday Returns $=8.42 \times 10^{-5}+0.047 \operatorname{Resid}(-1)^{2}+0.767$ Garch $(-$ 1)

Table 7: Mean Equation Estimation Using the ARCH Model

\begin{tabular}{|l|l|l|l|l|}
\hline Variable & \multicolumn{1}{|l|}{ Coefficient } & Std. Error & & Prob. \\
\hline C & -0.001 & 0.0007 & & 0.046 \\
\hline & \multicolumn{3}{|l|}{ Variance Equation } \\
\hline C & $8.42 \mathrm{E}-05$ & $4.66 \mathrm{E}-05$ & & 0.071 \\
RESID(-1)^2 & 0.047 & 0.022 & 0.034 \\
GARCH(-1) & 0.767 & 0.120 & 0.000 \\
\hline
\end{tabular}

Source: Processed data (2017)

The ARCH model (Table 7) estimation results analysis displays the resid(-1)2 coefficient or ARCH(-1) and GARCH(-1) each of 0.047571 and 0.766723 . The equation mean coefficient or equation variance are both significant (prob. less than 5\%). Therefore, the Monday return behavior can be explained with the GARCH(1.1) model, meaning that the Monday returns followed the $\mathrm{ARCH}(-1)$ process and the $\mathrm{GARCH}(-1)$ process. Based on this testing, it can be concluded that the Monday return data had clustering volatility. The testing would be continued by using a volatility $(\mathrm{GARCH})$ model estimation with Friday returns as the independent variable.

Table 8: GARCH Volatility Model Estimation Volatilitas GARCH

\begin{tabular}{|l|l|l|l|}
\hline Variable & Coefficient & Std. Error & Prob. \\
\hline Return_Friday & -0.00013 & $9.90 \mathrm{E}-05$ & 0.198 \\
C & 0.0005 & $2.30 \mathrm{E}-06$ & 0.000 \\
\hline
\end{tabular}

Source: Processed data (2017)

The Friday return coefficient was -0.00013 with a probability of 0.198 (Table 8). This significant probability was higher than 5\%, so that it could be concluded that the Friday returns did not convey a real influence towards Monday return volatility. These results were also supported by a significant and positive constant value, even though the coefficient value was very small, meaning that the Monday returns were formed by the Monday returns itself. It seems the previous Friday negative returns (bad Friday) did not affect the Monday effect phenomenon. This finding indicates that the Monday returns were formed from investor behavior and sentiment itself when doing trading transactions (Baker \& Wurgler, 2007; Lakonishok \& Maberly, 1990; Mills \& Andrew Coutts, 1995). When reviewed from the psychological/emotional aspect, investors do not tend to like Mondays as the beginning of the work day, so that they feel pessimistic when doing transactions in the stock market. The lowest trading volume averages appeared on Mondays, where the stock trading volume averages were for five stock market days. If seen from the descriptive statistics, there were differences, but not outstanding ones. The Friday returns were not an influential variable, but it is suspected that this variable could become a constant or forming variable from the Monday returns. The Friday returns were the basis, in keeping in mind of how the Monday returns were formed.

Table 9: OLS Estimation Using Initial Data (Monday Returns as a Dependent Variable and Friday Returns as an Independent Variable)

\begin{tabular}{|l|l|l|l|}
\hline Variable & Coefficient & Std. Error & Prob. \\
\hline Return_Friday & 0.060 & 0.028 & 0.034 \\
\hline
\end{tabular}

Source: Processed data (2017)

As a comparison, an analysis was also conducted on the Friday returns towards the Monday returns using initial data with a regression analysis. The results are displayed in Table 8 , in that the Friday returns influenced the Monday returns in a significant and positive way. From these two analyses, it was seen that Monday returns were related with Friday returns, where Friday returns were indications of taking profit and Monday returns were investor measures to begin their investment activities based on the Friday conditions.

\subsection{Testing the Influence of Trading Volume and Frequency towards Monday Stock Returns (Hypothesis 3)}

The following testing results are explained for Monday return predictions based on differences in trading volume and frequency for those two days.

Table 10: ARCH-GARCH Model Estimations

\begin{tabular}{|l|l|l|l|}
\hline Variable & Coefficient & Std. Error & Prob. \\
\hline $\mathrm{C}$ & -0.00134 & 0.000674 & 0.046 \\
\hline \multicolumn{4}{|l|}{ Variance Equation } \\
\hline $\mathrm{C}$ & $8.42 \mathrm{E}-05$ & $4.66 \mathrm{E}-05$ & 0.071 \\
RESID $(-1)^{\wedge} 2$ & 0.047 & 0.022407 & 0.034 \\
GARCH(-1) & 0.767 & 0.120306 & 0.000 \\
\hline
\end{tabular}

Source: Processed data (2017)

The equation produced from the output above is stated as follows: Return_Monday $=8,42$ x 10-5 + 0,047 Resid(-1)2 + 0,767 Garch(1) The analysis of estimation results in Table 10 reveals a resid($1)^{\wedge} 2$ probability value or $\mathrm{ARCH}(-1)$ and $\operatorname{GARCH}(-1)$ each of 0.0338 and 0.000 are all significant. This means that the Monday returns followed an $\mathrm{ARCH}(-1)$ process and $\mathrm{GARCH}(-1)$ process, so that the Monday return data had clustering volatility. Next, the volatility model $(\mathrm{GARCH})$ was estimated with the trading volume and frequency on Mondays as an independent variable. Before doing a GARCH model estimation, a Monday trading volume and frequency stationarity test was conducted using ADF (Table 11 and Table 12).

Table 11: ADF Test of Monday Trading Volume (Monday Volume)

\begin{tabular}{|l|l|l|l|}
\hline Variable & t-Statistic & Prob. \\
\hline Augmented Dickey-Fuller test statistic & -4.706 & 0.0001 \\
\hline *MacKinnon (1996) one-sided p-values
\end{tabular}

Source: Processed data (2017)

Table 12: ADF Test of Monday Trading Frequency (Monday Frequency)

\begin{tabular}{|l|l|l|}
\hline Variable & t-Statistic & Prob. \\
\hline Augmented Dickey-Fuller test statistic & -5.919 & 0.000 \\
\hline *MacKinnon (1996) one-sided p-values \\
\hline
\end{tabular}

Source: Processed data (2017)

It was found that the ADF had a significant value below 5\%, which means that the Monday trading volume showed a stationary condition. Likewise, the Monday trading frequency data stationarity test displayed a stationary condition. Therefore, for the next estimation, it was not necessary to do differentiating of the trading volume and frequency data on Mondays. The Monday return estimations were based on the Monday stock trading frequency and volume by using the GARCH model. It can be stated that the Monday returns were influenced by the trading frequency on Mondays. Meanwhile, the trading volume was not a determinant factor (Table 13).

Table 13: Monday Return Estimation Based on Trading Volume and Frequency

\begin{tabular}{|l|l|l|l|}
\hline Variable & Coefficient & Std. Error & Prob. \\
\hline Volume_Monday & $-2.25 \mathrm{E}-14$ & $1.22 \mathrm{E}-14$ & 0.066 \\
Frequency_Monday & $4.23 \mathrm{E}-09$ & $1.15 \mathrm{E}-09$ & 0.0003 \\
C & 0.0004 & $3.46 \mathrm{E}-06$ & 0.000 \\
\hline
\end{tabular}

Source: Processed data (2017)

The next testing estimated the Monday returns based on the difference/delta of trading volume or frequency on FridayMonday. First, a data stationarity test was done from the trading volume delta or frequency from Friday-Monday. The following is the formal test results in using ADF.

Table 14: ADF Test Results of the Friday-Monday Trading Volume Delta

\begin{tabular}{|l|l|l|}
\hline Variable & t-Statistic & Prob. \\
\hline Augmented Dickey-Fuller test statistic & -7.7461 & 0.000 \\
\hline *MacKinnon (1996) one-sided p-values
\end{tabular}


Table 15: ADF Test Results of the Friday-Monday Trading Frequency Delta

\begin{tabular}{|l|l|l|}
\hline Variable & t-Statistic & Prob. \\
\hline Augmented Dickey-Fuller test statistic & -11.797 & 0.000 \\
\hline *MacKinnon (1996) one-sided p-values
\end{tabular}

Source: Processed data (2017)

Table 14 and Table 15 reveal that the trading volume or frequency delta data tended to be stationary, because it did not contain unit roots (a significance of less than 5\%). Based on Table 16, the Monday returns were influenced by the trading frequency delta on Friday-Monday, but the trading volume delta was not a determinant factor because it was not statistically proven. When the trading frequency increased, it would become a positive signal for investors to buy stocks. If this occurred, then the stock prices would increase because the trading activities would increase, and in the end the Monday returns would increase. Compared with the trading volume, it seems investors were more interested in the trading frequency, because the frequency usually showed rational and sustainable interconnectedness compared with the trading volume, which tended to be speculative and subjective. Baron, Brogaard (71) stated that companies which have high trading frequency will receive high returns compared with companies which have low trading frequency.

Table 16: Monday Return Estimations Based on Trading Volume and Frequency Delta

\begin{tabular}{|l|l|l|l|}
\hline Variable & Coefficient & Std. Error & Prob. \\
\hline Delta_Volume & $-1.40 \mathrm{E}-14$ & $3.99 \mathrm{E}-14$ & 0.727 \\
Delta_Frequency & $2.62 \mathrm{E}-09$ & $7.85 \mathrm{E}-10$ & 0.001 \\
C & 0.0004 & $2.28 \mathrm{E}-06$ & 0.000 \\
\hline
\end{tabular}

Source: Processed data (2017)

The high frequency of trading had a positive correlation with the stock price volatility after controlling the company fundamental volatility and other exogen volatility determining factors. Positive correlations also strengthened during periods of high market uncertainty. Trading with a high frequency had a negative relationship with the market ability to input information about company fundamental aspects to asset prices. Stock prices tended to overreact towards fundamental news during high frequency trading with a high volume (72). High frequency trading provided liquidity if it was already seldom and consumed much liquidity. Prices provide more efficient information when issuers participate in a high frequency (73).

\section{Conclusion}

Stock returns are greatly determined by the stock trading days. It seems there is a strong correlation between the days in which the stocks are sold with the level of buying done by investors. This finding can be seen from the real differences between the return averages for 5 trading days in the stock market. This finding is in line with that found by Abraham and Ikenberry (4) and Berument and Kiymaz (20) . This research also revealed that returns are negative on Fridays, and even the lowest compared with returns on other days. This infers that this research can also validate the presence of a Friday effect. Besides having negative returns on Fridays, this research also conveyed that there are negative returns on Mondays. This confirms that there is a Monday effect, where the negative effects from a Friday still continue to the next Monday, even though it tends to improve with higher returns than on the previous Friday.

This research was unable to substantiate a correlation between returns on a Friday with returns on a Monday. In other words, negative returns on a Monday were not significantly influenced by negative returns that occurred on a Friday. Despite this, there was a tendency for Friday returns to have a positive response with Monday returns, which were better than on a Friday. Friday returns were negative, keeping in mind that stock prices were con- sidered as being overvalued and due to the action of investors taking profit. Meanwhile, although Monday returns tended to increase, they were still negative because of investors' psychological condition from the Monday effect $(19,36,68)$

Monday returns were influenced by trading frequency delta, not by trading volume delta. This means that the trading frequency was more "meaningful" for investors and became a signal to buy or sell their stocks, which would influence their returns $(72,73)$. At the time investors did not have clear guidelines to do transactions, they generally chose stocks that had high trading frequency to invest $(71,74)$. Meanwhile, the Monday trading volume was not shown to influence Monday returns. These results are different with previous research $(9,75-78)$, in that trading volume had a positive influence on return volatility. These results support research conducted by Jain (1988) and Lee and Rui (79), who stated that trading volume does not have a significant influence on returns.

\subsection{Research Limitations and Suggestions}

This research could not prove a significant relationship between negative returns on Fridays with negative returns on Mondays. When Monday returns followed a clustering volatility pattern, so that they had to be tested by using a GARCH model, the Friday returns were not return determinants on Mondays. However, when this clustering volatility was disregarded, the returns on Fridays actually become the determinant factor. When investors do stock and return price estimations, which model will be used? This is an important issue to be answered by doing future research by adding further observations during normal market conditions, because this research was conducted during abnormal conditions (there were many demonstrations on Fridays).

The returns on Fridays fluctuated more per issuer compared with returns on Mondays that tended to be more stable and gradually increased cross-sectionally. How could this occur? Was there a relationship with the issuer performance or not? Was there a connection with the investor psychological aspect, as in evaluating risk acceptance towards stocks on Mondays? Research related with this is very relevant to be carried out in the future.

The trading volume in numerous previous literature and research shows that there is an influence on price volatility and stock returns. However, in this research, this condition could not be validated, where Sunday trading volume did not influence stock returns on that day. Why did this condition occur? Is it possible that liquidity, risks, or other variables caused it? A research topic like this should be conducted to find answers to these questions.

\section{Acknowledgement}

This research was conducted as one of the doctoral study requirements of Diponegoro University, Semarang, Central Java, Indonesia. The funding for this study was supported by a 2016 Indonesia Lecturer Top Scholarship (BUDI) that originated from the Education Finance Management Institution of the Ministry of Finance of the Republic of Indonesia.

\section{References}

[1] Boutchkova M, Doshi H, Durnev A, Molchanov A. Precarious politics and return volatility. The Review of Financial Studies. 2011;25(4):1111-54

[2] Jensen NM, Schmith S. Market responses to politics: The rise of Lula and the decline of the Brazilian stock market. Comparative Political Studies. 2005;38(10):1245-70.

[3] Arin KP, Molchanov A, Reich OF. Politics, stock markets, and model uncertainty. Empirical Economics. 2013;45(1):23-38.

[4] Abraham A, Ikenberry DL. The individual investor and the weekend effect. Journal of Financial and Quantitative Analysis. 1994;29(02):263-77. 
[5] Tong W. International evidence on weekend anomalies. Journal of financial research. 2000;23(4):495-522.

[6] Puryandani S. The Javanese lunar calendar's effect on Indonesian stock returns. Gadjah Mada International Journal of Business. 2015;17(2):125.

[7] Sun Q, Tong WH. Another new look at the Monday effect. Journal of Business Finance \& Accounting. 2002;29(7-8):1123-47.

[8] Engelberg J, McLean RD, Pontiff J. Anomalies and news. Journal of Finance, Forthcoming. 2015;6th Miami Behavioral Finance Conference.

[9] Campbell JY, Grossman SJ, Wang J. Trading volume and serial correlation in stock returns. The Quarterly Journal of Economics. 1993;108(4):905-39.

[10] O'Hara M. High frequency market microstructure. Journal of Financial Economics. 2015;116(2):257-70.

[11] Lamoureux CG, Lastrapes WD. Endogenous trading volume and momentum in stock-return volatility. Journal of Business \& Economic Statistics. 1994;12(2):253-60.

[12] Bromiley P, Govekar M, Marcus A. On using event-study methodology in strategic management research. Technovation. 1988;8(13):25-42.

[13] Henry PB. Stock market liberalization, economic reform, and emerging market equity prices. The Journal of Finance. 2000;55(2):529-64.

[14] Nelson KK, Price RA, Rountree BR. The market reaction to Arthur Andersen's role in the Enron scandal: Loss of reputation or confounding effects? Journal of Accounting and Economics. 2008;46(2-3):279-93.

[15] Bessembinder H, Hertzel MG. Return autocorrelations around nontrading days. The Review of Financial Studies. 1993;6(1):155-89.

[16] Cross F. The behavior of stock prices on Fridays and Mondays. Financial analysts journal. 1973:67-9

[17] French KR. Stock returns and the weekend effect. Journal of financial economics. 1980;8(1):55-69.

[18] Fishe RP, Gosnell TF, Lasser DJ. Good news, bad news, volume, and the Monday effect. Journal of Business Finance \& Accounting. 1993;20(6):881-92.

[19] Ajayi RA, Mehdian S, Perry MJ. The day-of-the-week effect in stock returns: further evidence from Eastern European emerging markets. Emerging Markets Finance and Trade. 2004;40(4):53-62.

[20] Berument H, Kiymaz H. The day of the week effect on stock market volatility. Journal of economics and finance. 2001;25(2):181-93

[21] Najand M, Yung K. Conditional heteroskedasticity and the weekend effect in S\&P 500 index futures. Journal of Business Finance \& Accounting. 1994;21(4):603-12.

[22] Gibbons MR, Hess P. Day of the week effects and asset returns. Journal of business. 1981:579-96.

[23] Pettengill GN. A survey of the Monday effect literature. Quarterly Journal of Business and Economics. 2003;42(3/4):3-27.

[24] Johnston ET, Kracaw WA, McConnell JJ. Day-of-the-week effects in financial futures: An analysis of GNMA, T-bond, T-note, and Tbill contracts. Journal of Financial and Quantitative Analysis. 1991;26(01):23-44.

[25] Bollerslev T, Cai J, Song FM. Intraday periodicity, long memory volatility, and macroeconomic announcement effects in the US Treasury bond market. Journal of empirical finance. 2000;7(1):3755.

[26] McFarland JW, Pettit RR, Sung SK. The distribution of foreign exchange price changes: trading day effects and risk measurement. the Journal of Finance. 1982;37(3):693-715.

[27] Yamori N, Kurihara Y. The day-of-the-week effect in foreign exchange markets: multi-currency evidence. Research in Internationa Business and Finance. 2004;18(1):51-7.

[28] Chukwuogor CN. An econometric investigation of the day-of-theweek effect and returns volatility in fifteen Asia Pacific financial markets (1998-2003). 2008.

[29] Muhammad NMN, Rahman NMNA. Efficient market hypothesis and market anomaly: Evidence from day-of-the week effect of Malaysian exchange. International Journal of Economics and Finance. 2010;2(2):35.

[30] Glosten LR, Jagannathan R, Runkle DE. On the relation between the expected value and the volatility of the nominal excess return on stocks. The journal of finance. 1993;48(5):1779-801.

[31] Engle R. GARCH 101: The use of ARCH/GARCH models in applied econometrics. Journal of economic perspectives. 2001;15(4):157-68.

[32] Bauwens L, Laurent S. A new class of multivariate skew densities, with application to generalized autoregressive conditional hetero- scedasticity models. Journal of Business \& Economic Statistics. 2005;23(3):346-54

[33] Malkiel BG, Fama EF. Efficient capital markets: A review of theory and empirical work. The journal of Finance. 1970;25(2):383-417.

[34] Fama EF. Efficient market: A review of theory and empirical work. Journal of Finance 1970;25(2):383-417.

[35] Rogalski RJ. New findings regarding day-of-the-week returns over trading and non-trading periods: a note. The Journal of Finance. 1984;39(5):1603-14

[36] Mills TC, Andrew Coutts J. Calendar effects in the London Stock Exchange FT-SE indices. The European Journal of Finance. 1995;1(1):79-93

[37] McGowan Jr CB, Ibrihim I. An analysis of the day-of-the-week effect in the Russian stock market. International Business \& Economics Research Journal (IBER). 2011;8(9).

[38] James G, Shaban M. The effects of ownership change on bank performance and risk exposure: Evidence from Indonesia. 2017.

[39] Feng L, Seasholes MS. Do investor sophistication and trading experience eliminate behavioral biases in financial markets? Review of Finance. 2005;9(3):305-51.

[40] Wong KA, Hui TH, Chan CY. Day-of-the-week effects: evidence from developing stock markets. Applied Financial Economics. 1992;2(1):49-56

[41] Wang K, Li Y, Erickson J. A new look at the Monday effect. The Journal of Finance. 1997;52(5):2171-86.

[42] Jaffe JF, Westerfield R, Ma C. A twist on the Monday effect in stock prices: Evidence from the US and foreign stock markets. Journal of Banking \& Finance. 1989;13(4-5):641-50.

[43] Hirshleifer D, Shumway T. Good day sunshine: Stock returns and the weather. The Journal of Finance. 2003;58(3):1009-32.

[44] Michayluk D, Neuhauser KL. Investor overreaction during market declines: Evidence from the 1997 Asian financial crisis. Journal of Financial Research. 2006;29(2):217-34.

[45] Chaopricha P, Chan P, Pollard D. Firm Characteristics and Stock Return. International DSI/Asia and Pacific DSI. 2007.

[46] Malkiel BG. The efficient market hypothesis and its critics. Journal of economic perspectives. 2003;17(1):59-82.

[47] Lakonishok J, Shleifer A, Vishny RW. Contrarian investment, extrapolation, and risk. The journal of finance. 1994;49(5):1541-78.

[48] Drew ME, Naughton T, Veeraraghavan M. Firm size, book-tomarket equity and security returns: Evidence from the Shanghai Stock Exchange. Australian Journal of Management. 2003;28(2):119-39.

[49] Basu S. Investment performance of common stocks in relation to their price-earnings ratios: A test of the efficient market hypothesis The journal of Finance. 1977;32(3):663-82.

[50] Breen W. Low price-earnings ratios and industry relatives. Financial Analysts Journal. 1968:125-7.

[51] Dreman D. Let Regression Be your Guide. Forb (November 24, 1980). 1980:210-1.

[52] Kandir SY. Macroeconomic variables, firm characteristics an stock returns: evidence from Turkey. International research journal of finance and economics. 2008;16(1):35-45.

[53] Hou K, Robinson DT. Industry concentration and average stock returns. The Journal of Finance. 2006;61(4):1927-56.

[54] Bodnar GM, Gentry WM. Exchange rate exposure and industry characteristics: evidence from Canada, Japan, and the USA. Journal of international Money and Finance. 1993;12(1):29-45.

[55] Barclay MJ, Litzenberger RH, Warner JB. Private information, trading volume, and stock-return variances. Review of Financia Studies. 1990;3(2):233-53.

[56] Elvira R. Pengaruh Aktivitas Perdagangan terhadap Return Saham Syariah Perusahaan yang Listing di Jakarta Islamic Index (JII) Periode 2012-2014. Madania: Jurnal Kajian Keislaman. 2016;20(1):101-14.

[57] Handa P, Schwartz RA. How best to supply liquidity to a securities market. The Journal of Portfolio Management. 1996;22(2):44-51.

[58] Becker-Blease JR, Paul DL. Stock liquidity and investment opportunities: Evidence from index additions. Financial Management. 2006;35(3):35-51.

[59] Field A. Discovering Statistics Using SPSS. London: SAGE Publications Ltd; 2009.857 p

[60] Engle RF. Autoregressive conditional heteroscedasticity with estimates of the variance of United Kingdom inflation. Econometrica: Journal of the Econometric Society. 1982:987-1007.

[61] Bollerslev T. Generalized autoregressive conditional heteroskedasticity. Journal of econometrics. 1986;31(3):307-27. 
[62] Engle III RF, Ito T, Lin W-L. Meteor showers or heat waves? Heteroskedastic intra-daily volatility in the foreign exchange market. National Bureau of Economic Research Cambridge, Mass., USA; 1988.

[63] Baillie RT, Bollerslev T. A multivariate generalized ARCH approach to modeling risk premia in forward foreign exchange rate markets. Journal of International Money and Finance. 1990;9(3):309-24

[64] Bollerslev T, Engle RF, Nelson DB. ARCH models. Handbook of econometrics. 1994;4:2959-3038

[65] Akgiray V. Conditional heteroscedasticity in time series of stock returns: Evidence and forecasts. Journal of business. 1989:55-80.

[66] French KR, Schwert GW, Stambaugh RF. Expected stock returns and volatility. Journal of financial Economics. 1987;19(1):3-29.

[67] Timmermann A, Granger CW. Efficient market hypothesis and forecasting. International Journal of forecasting. 2004;20(1):15-27.

[68] Lakonishok J, Maberly E. The weekend effect: Trading patterns of individual and institutional investors. The Journal of Finance. 1990;45(1):231-43.

[69] Zhang X, Fuehres H, Gloor PA. Predicting stock market indicators through twitter "I hope it is not as bad as I fear". Procedia-Social and Behavioral Sciences. 2011;26:55-62.

[70] Baker M, Wurgler J. Investor sentiment in the stock market. Journal of economic perspectives. 2007;21(2):129-52.

[71] Baron MD, Brogaard J, Hagströmer B, Kirilenko AA. Risk and return in high-frequency trading. 2016.

[72] Zhang F. The effect of high-frequency trading on stock volatility and price discovery. SSRN eLibrary. 2010.

[73] Carrion A. Very fast money: High-frequency trading on the NASDAQ. Journal of Financial Markets. 2013;16(4):680-711.

[74] Brogaard J, Hendershott T, Riordan R. High-frequency trading and price discovery. The Review of Financial Studies. 2014;27(8):2267-306

[75] Andersen TG. Return volatility and trading volume: An information flow interpretation of stochastic volatility. The Journal of Finance. 1996;51(1):169-204

[76] Foster FD, Viswanathan S. Variations in trading volume, return volatility, and trading costs: Evidence on recent price formation models. The Journal of Finance. 1993;48(1):187-211.

[77] Brock WA, LeBaron BD. A dynamic structural model for stock return volatility and trading volume. National Bureau of Economic Research; 1995.

[78] Mubarik F, Javid AY. Relationship between stock return, trading volume and volatility: Evidence from Pakistani stock market. 2009.

[79] Lee CF, Rui OM. Does trading volume contain information to predict stock returns? Evidence from China's stock markets. Review of Quantitative Finance and Accounting. 2000;14(4):341-60. 